\title{
Tourism Destination Development Policies in the Regional Spatial System of Karangasem Regency, Bali, Indonesia
}

\author{
I Komang Gede Santhyasa (Corresponding Author) \\ Student of Tourism Doctoral Study Program, Tourism Faculty, Udayana University - \\ Indonesia \\ E-mail: santhyasa@unhi.ac.id
}

Syamsul Alam Paturusi

Professor at Engineering Faculty, Udayana University - Indonesia

E-mail: syamsul@unud.ac.id

I Nyoman Sunarta

Lecturer of Tourism Faculty, Udayana University - Indonesia

E-mail: nyoman_sunarta@unud.ac.id

I Nyoman Sukma Arida

Lecturer of Tourism Faculty, Udayana University - Indonesia

E-mail: sukma_arida@unud.ac.id

Received: May 20, 2020 Accepted: June 19, 2020 Published: June 30, 2020

doi:10.5296/ijssr.v8i2.17287 URL: http://dx.doi.org/10.5296/ijssr.v8i2.17287 


\title{
II Macrothink

\begin{abstract}
Facts on the tourism issues that emerged in Karangasem Regency showed a lack of synergy between spatial planning and tourism destination planning. In addition, tourism development in Karangasem Regency is vulnerable to exploitation of natural and cultural resources. Therefore, in developing tourism in Karangasem Regency, careful measures are needed to avoid the degradation of local cultural values. This study aimed to formulate and develop a policy framework for tourism destination development in the regional spatial system of Karangasem Regency, Bali, Indonesia. This study used a qualitative research approach with multicriteria-based policy (MULTIPOL) analysis. The data were collected through document studies, interviews, and focus group discussions (FGD). MULTIPOL analysis integrates a participatory approach into multi-criteria principles, and therefore, the MULTIPOL framework is based on the information obtained from stakeholders through FGD. In this study, the interviewees were chosen through purposive sampling by involving 15 experts consisting of 3 community leaders, 7 local government officials, and 5 managers of tourist attractions. The results showed that the tourism village development action scored the highest for the conservation-based tourism policy, regional potential-based tourism policy, infrastructure development and accessibility policy, and community-based tourism management policy. Meanwhile, the highest-scoring policies in relation to the established integrated development scenarios, are the regional potential-based tourism policy, the community-based tourism management policy, and the conservation-based tourism policy.
\end{abstract}

Keywords: policies, tourism destinations, spatial, regional potential, integrated development 


\section{Introduction}

Tourism development requires spatial system to accommodate its tourism activities. Tourism development and spatial system are closely related to policies that create a synergy in the relationship between the two (Ruhanen, 2004). Tourism development with its tourism activities should operate in the spatial zone which is designated for tourism activities (Papageorgiou and Beriatos, 2011; Risteski et al., 2012; Chettiparamb \& Thomas, 2012). Tourism development in an area must refer to the Regional Spatial Plan in the area concerned as mandated in Law No. 26 of 2007 on Spatial Planning (Republik Indonesia, 2007).

Based on the area, the Republic of Indonesia's Government Regulation Number 50 of 2011 on the National Tourism Development Master Plan for 2010-2025 has determined Bali-Nusa Lembongan and its surroundings as a National Tourism Destination with 11 areas as National Tourism Strategic Areas (Republik Indonesia, 2011). In addition to that, seen from the spatial planning, the tourism areas on the island of Bali are spread across all regencies/municipalities in the province of Bali. In fact, Bali Island is almost evenly divided by the development of tourism areas in the form of Tourism Strategic Areas and Special Tourist Attraction Areas. Development of tourism areas has become a policy in tourism spatial planning as outlined in the Regional Regulation of Bali Province Number 16 of 2009 on Spatial Planning of Bali Province in the period of 2009-2029 (Provinsi Bali, 2009).

The regional and spatial planning policy places Karangasem Regency in a strategic position in tourism development. There are three National Tourism Strategic Areas in Karangasem Regency, namely Karangasem-Amuk, Besakih-Mount Agung, and Tulamben-Amed, as well as three Tourism Strategic Areas, namely Candidasa, Ujung, and Tulamben, and other tourist attractions scattered in Karangasem Regency. However, this strategic position does not necessarily make tourism in Karangasem Regency progress.

On a regional basis, the development of tourism in Bali is still dominant in the southern part of Bali, such as in Badung Regency. Meanwhile, the eastern part of Bali, especially Karangasem Regency, is not yet well developed. At present, economic inequality occurs because the amount of investment in the southern Bali region is far exceeding that in other regencies/municipalities. As a result, tourism infrastructure is concentrated in the southern part of Bali. Around 70\% of tourist accommodations in Bali are centered in Badung Regency (BPS Provinsi Bali, 2018).

The development of tourism which is concentrated in the southern part of Bali results in the regional activity centers and infrastructure development being centered on the southern part of Bali, while the eastern end of the Bali region namely Karangasem Regency is still lagging behind. Again, based on the data from the BPS (Bureau of Statistics) of Bali Province (2018), Karangasem Regency, in terms of poverty rate, occupies the top position with a poverty rate reaching $6.65 \%$ in Bali. This means that the level of welfare in Karangasem Regency is still far behind compared to other regions in Bali.

The spatial regulation of tourism areas in Karangasem Regency has been specifically laid out in the Regional Regulation of Karangasem Regency Number 17 of 2012 on Regional Spatial 
Planning of Karangasem Regency for the period of 2012-2032 (Kabupaten Karangasem, 2012). However, this Regional Regulation on Regional Spatial Planning has not yet become a reference base in tourism development in Karangasem Regency. This condition can be seen from the presence of tourist accommodations existing outside the established tourism areas, and the emergence of tourist attractions without detailed spatial plans.

Karangasem Regency which is located in the northern part of Bali Island has Mount Agung and Besakih Temple which are the most significant spiritual symbols of Hindu civilization in Bali. Therefore, in developing tourism in Karangasem Regency, careful measures are needed to avoid the degradation of local cultural values. The role of Karangasem Regency as the northern part of Bali Island and its unique tourism potential such as spiritual tourism lead to consequences and impacts on stakeholders' treatment, especially the local governments' treatment of various relics of spiritual sites (such as large Hindu temples) in Karangasem Regency.

The facts on the tourism issues that emerged in Karangasem Regency showed a lack of synergy between spatial planning and tourism destination planning. Spatial planning and tourism destination planning are carried out partially, and this results in the development of tourism that is not based on the established spatial plan and the possessed regional potential (Lew, 2017).

If the issues in the efforts to develop tourism are left unchecked, there can be serious problems which may occur, especially in the cultural development, and other problems such as fading social cohesion, and natural environment degradation. Some parties are concerned about the problem of the increasingly distant social life of the people from their cultural roots, namely the agrarian culture, and other problems including marginalization and degradation of the local culture which is quite serious due to the advancing wave of modernization through the tourism industry (Putra and Paturusi, 2017).

In developing tourism destinations in Karangasem Regency, a contextual planning approach is needed based on the potential of the region, the characteristics of the community, as well as the influence of the applicable local policies and cultural values (Djunaedi, 2012). The planning approach gives an overview of the planning process that has been practiced to date to understand the dominance of the power of planning and the influence of policies on the development of tourism destinations.

Based on the complexity of tourism issues and their impacts on the spatial planning of Karangasem Regency, the research problems are as follows: the Regional Spatial Plan of Karangasem Regency has not become a reference base for tourism development in Karangasem Regency; the tourism development in Karangasem Regency is still running slowly; and tourism development in Karangasem Regency is vulnerable to exploitation of natural and cultural resources. This research was conducted to provide some contribution in the formulation and development of a policy framework that is appropriate for tourism destination development in the regional spatial system in Karangasem Regency of Bali, Indonesia. 


\section{Research Methods}

This study used a qualitative method approach with multicriteria-based policy analysis (Godet, 2001; Godet et al., 2004; Panagiotopoulou and Sratigea, 2014). MULTIPOL (Multicriteria Policy) analysis evaluates the choice of actions not only against the criteria used, but also the interaction of three components, namely actions, policies, and scenarios.

The interaction of these three components results in two types of evaluation in MULTIPOL as explained by Stratigea et al. (2013) and Fauzi (2019). The first one is actions-to-policies-based evaluation. This evaluation determines the actions that are most appropriate for each policy, resulting in a hierarchy of impacts of actions to policies. The second type of evaluation is called policies-to-scenarios-based evaluation. This evaluation determines the policies that are most appropriate for a particular scenario, resulting in a hierarchy of policies and their impacts on each scenario. In addition to the three main components as inputs, MULTIPOL requires criteria that will be used when assessing scenarios, policies and actions. These components will be assessed through a matrix of the three components and the established criteria. The criteria describe measurable aspects based on the assessment given by the stakeholders.

The data were collected through document studies, interviews, and focus group discussions (FGD). MULTIPOL analysis integrates a participatory approach (Bello et al., 2016) into multi-criteria principles, and therefore, the MULTIPOL framework is based on the information obtained from the stakeholders through FGD. In this study, the interviewees were chosen through purposive sampling by involving 15 experts consisting of 3 community leaders, 7 local government officials, and 5 managers of tourist attractions.

\section{Results and Discussion}

3.1 Components of evaluation criteria, policies, actions, and scenarios for developing tourism destinations in Karangasem Regency

The development of an area, including the development of a tourism destination with an emphasis on the policy, is strongly related to the aspect of sustainability. Through the FGD, evaluation criteria were formulated based on the established spatial planning objectives that had been outlined in the Regional Spatial Plan of Karangasem Regency for the period of 2012-2032. The spatial planning objectives were used as a reference, considering that this research stemmed from the idea that tourism planning can contribute to realizing better spatial planning objectives. Based on the Regional Spatial Plan, the spatial planning objectives of Karangasem Regency include the realization of a prosperous Karangasem region through the development of agrobusinesses and tourism that are sustainable and environmentally sound in the use of space that incorporates disaster mitigation aspects (Table $1)$. 
Table 1. Criteria for developing Karangasem Regency tourism destinations

\begin{tabular}{|c|l|l|c|}
\hline No. & \multicolumn{1}{|c|}{ Objectives } & \multicolumn{1}{|c|}{ Criteria } & Code \\
\hline \multirow{2}{*}{1} & \multirow{2}{*}{ Prosperity/economy } & Increased local revenues & $\mathrm{C} 1$ \\
\cline { 3 - 4 } & & Increased employment & $\mathrm{C} 2$ \\
\cline { 3 - 4 } & & Increased community income & $\mathrm{C} 3$ \\
\cline { 3 - 4 } & & Reduced poverty & $\mathrm{C} 4$ \\
\hline 2 & \multirow{2}{*}{$\begin{array}{l}\text { Agrobusiness } \\
\text { development }\end{array}$} & Growth of new businesses & $\mathrm{C} 5$ \\
\cline { 3 - 4 } & \multirow{2}{*}{$\begin{array}{l}\text { Sustainable and } \\
\text { environmentally } \\
\text { friendly tourism }\end{array}$} & Increased regional competitiveness & $\mathrm{C} 6$ \\
\cline { 3 - 4 } & & Increased cultural preservation efforts & $\mathrm{C} 7$ \\
\cline { 3 - 4 } & \multirow{2}{*}{$\begin{array}{l}\text { Spatial use that } \\
\text { incorporates disaster } \\
\text { mitigation aspects }\end{array}$} & Increased tourist satisfaction & $\mathrm{C} 8$ \\
\cline { 3 - 4 } & \multirow{2}{*}{\begin{tabular}{l} 
Increased tourist visits \\
\cline { 3 - 4 }
\end{tabular}} & Reduced land use change & $\mathrm{C}$ C10 \\
\cline { 3 - 4 } & & Reduced inequality in regional growth & $\mathrm{C} 13$ \\
\cline { 3 - 4 } & & Increased regional investment opportunities & $\mathrm{C} 14$ \\
\cline { 3 - 4 } & Reduced disaster risk & $\mathrm{C} 15$ \\
\hline
\end{tabular}

Source: FGD (2020), processed from Regional Spatial Plan of Karangasem Regency for the Period of 2012-2032

The spatial planning objectives are translated into evaluation criteria in developing Karangasem Regency tourism destinations. The criteria are increased local revenues $(\mathrm{C} 1)$, increased employment $(\mathrm{C} 2)$, increased community income $(\mathrm{C} 3)$, reduced poverty $(\mathrm{C} 4)$, growth of new businesses ( $\mathrm{C} 5$ ), increased regional competitiveness (C6), increased cultural preservation efforts $(\mathrm{C} 7)$, reduced environmental damage (C8), increased tourist satisfaction (C9), increased tourist visits (C10), reduced land use change (C11), improved infrastructure network (C12), reduced inequality in regional growth (C13), increased regional investment opportunities (C14), and reduced disaster risk (C15).

The FGD also formulated policies and actions for the development of more sustainable tourism destinations. The policies agreed upon in the FGD forum consist of five key policies produced based on the established indicators of the sustainability of tourism destinations in Karangasem Regency. The five key policies are as follows:

1) The first policy (P1): Tourism planning regulations. The emphasis of this policy is on the regulations which form the legal basis as a blueprint for tourism development in Karangasem Regency. The academic paper, the tourism development master plan of Karangasem Regency, was completed in 2016, but up until now it has not been set out in any regional regulations, hence it has not had any legal force to be the basis for planning tourism destinations.

2) The second policy (P2): Conservation-based tourism. The second policy is emphasized on tourism development that pays attention to the aspects of natural and environmental 
protection as well as socio-cultural preservation. This policy is important considering that Karangasem Regency has a 78.5\% area which is categorized as a protected area. In addition, from its social and cultural standpoints, Karangasem Regency has a variety of authentic customs and cultures that must be preserved.

3) The third policy (P3): Regional potential-based tourism. The emphasis of this policy is on tourism development that is based on the potential of local natural resources and culture to be the icon of the regional development with a one product-one village approach which was programmed by the government of Karangasem Regency.

4) The fourth policy (P4): Infrastructure development and accessibility. This policy emphasizes the support of infrastructure networks and accessibility in achieving sustainable tourism development.

5) The fifth policy (P5): Community-based tourism management. This policy is more focused on the management of tourist attractions by local communities in the context of empowering the community and strengthening the participatory planning model in tourism development.

Another input component needed for MULTIPOL implementation is actions for the development of tourism destinations. The FGD resulted in actions offered to realize the five established key policies shown in Table 2.

Table 2. Actions for the development of Karangasem Regency tourism destinations

\begin{tabular}{|c|c|l|}
\hline No. & Code & \\
\hline 1 & A1 & Development of a tourist attraction master plan \\
\hline 2 & A2 & Development of spiritual tourism \\
\hline 3 & A3 & Development of local resource-based tourism \\
\hline 4 & A4 & Management of tourism destinations \\
\hline 5 & A5 & Development of accessibility/connectivity between tourist attractions \\
\hline 6 & A6 & Capacity building and improvement of local community knowledge \\
\hline 7 & A7 & Development of Information, Communication and Technology (ICT) \\
\hline 8 & A8 & Development of tourism villages \\
\hline 9 & A9 & Development of agrotourism in rural areas \\
\hline 10 & A10 & Development of heritage tourism \\
\hline 11 & A11 & Establishment of conservation and cultivation zones in tourist areas \\
\hline 12 & A12 & $\begin{array}{l}\text { Enhancement of cross-sectoral, cross-governmental, and tourism actor } \\
\text { partnerships }\end{array}$ \\
\hline 13 & A13 & $\begin{array}{l}\text { Development of infrastructure networks as a facility to support tourism } \\
\text { activities }\end{array}$ \\
\hline 14 & A14 & Development of creative economy to support tourism businesses \\
\hline 15 & A15 & Promotion of cultural products through various cultural festivals \\
\hline
\end{tabular}

Source: FGD (2020) 


\section{MInstitute ${ }_{\text {Int }}^{\text {Macrothink }}$}

The FGD forum used a community-based tourism sustainability model approach in formulating the scenarios, namely the tourism destination open development scenario (S1), and the tourism destination integrated development scenario (S2).

\subsection{Policy framework for developing tourism destinations in Karangasem Regency}

In MULTIPOL analysis, the interaction of these three components (actions, policies, and scenarios) results in two types of evaluation.

\subsubsection{Action-to-Policy-Based Evaluation}

As shown in Table 3, the highest scoring actions are the development of tourism villages (A8), development of local resource-based tourism (A3), development of agrotourism in rural areas (A9), development of heritage tourism (A10), development of a tourist attraction master plan (A1), development of spiritual tourism (A2), and development of creative economy to support tourism businesses (A14). The seven actions are key ones since they have a strong degree of influence with very little dependency. The capacity building and improvement of local community knowledge action (A6), despite having a relatively small standard deviation, has a small score for each policy, and thus making it the lowest scoring action among all.

Table 3. Action-and-policy-based evaluation

\begin{tabular}{|c|c|c|c|c|c|c|c|c|}
\cline { 2 - 9 } \multicolumn{1}{c|}{} & P1 & P2 & P3 & P4 & P5 & Moy. & Ec. Ty & Number \\
\hline A1 & 17.6 & 18.8 & 13.2 & 16.4 & 12.8 & 15.9 & 2.4 & 11 \\
\hline A2 & 14.1 & 15.5 & 14.6 & 12.8 & 15.7 & 14.5 & 1 & 10 \\
\hline A3 & 16.5 & 18.4 & 17.2 & 15.6 & 18.6 & 17.3 & 1.1 & 14 \\
\hline A4 & 9.9 & 10.9 & 8.9 & 12.1 & 11.1 & 10.6 & 1 & 3 \\
\hline A5 & 11.9 & 11.1 & 11.2 & 15.2 & 12.4 & 12.3 & 1.5 & 7 \\
\hline A6 & 6.3 & 6.8 & 9.4 & 7.3 & 11.1 & 8.1 & 1.8 & 1 \\
\hline A7 & 11.9 & 10.9 & 11.3 & 14.9 & 12.6 & 12.2 & 1.4 & 6 \\
\hline A8 & 17 & 19 & 18.2 & 17 & 19.1 & 18 & 0.9 & 15 \\
\hline A9 & 16.9 & 15.2 & 17.4 & 16.5 & 16 & 16.4 & 0.8 & 13 \\
\hline A10 & 15.9 & 17.4 & 16.2 & 14.9 & 16.9 & 16.3 & 0.8 & 12 \\
\hline A11 & 13.8 & 14.1 & 10.2 & 11.3 & 7.8 & 11.6 & 2.3 & 4 \\
\hline A12 & 9.7 & 8.6 & 11.8 & 9.9 & 10.4 & 10 & 1 & 2 \\
\hline A13 & 12.9 & 11.4 & 12 & 16.1 & 12.6 & 13 & 1.6 & 8 \\
\hline A14 & 11.4 & 11.9 & 15.6 & 13.3 & 15.1 & 13.3 & 1.7 & 9 \\
\hline A15 & 9.3 & 12.4 & 11.4 & 11.6 & 13.8 & 11.6 & 1.5 & 4 \\
\hline
\end{tabular}

Source: MULTIPOL analysis results, 2020

This type of evaluation shows that the development of tourism village action (A8) excels at the conservation-based tourism policy $(\mathrm{P} 2)$, regional potential-based tourism policy (P3), infrastructure development and accessibility policy (P4), and community-based tourism 
management policy (P5). As for the tourism planning regulation policy (P1), the development of a tourist attraction master plan action (A1) scores higher than the other actions. This can be understood since tourism planning regulations rely more on the strength of regulations that have both legal force and a role as a blueprint (master plan) in developing tourism destinations of Karangasem Regency (Table 3).

Figure 1 presents the results of MULTIPOL in a closeness map which shows the closeness between policies and actions. Based on Figure 1, it can be explained as follows:

1) For the tourism planning regulation policy (P1), the actions that are closest and most relevant are the development of a tourist attraction master plan (A1) and the establishment of conservation and cultivation zones in tourist areas (A11).

2) For the conservation-based tourism policy (P2), the actions that are closest and most relevant are the development of a tourist attraction master plan (A1), the establishment of conservation and cultivation zones in tourism areas (A11), development of heritage tourism (A10), development of spiritual tourism (A2), development of local resource-based tourism (A3), and development of tourism villages (A8).

3) For the regional potential-based tourism policy (P3), the actions that are closest and most relevant are the development of agrotourism in rural areas (A9), enhancement of cross-sectoral, cross-government and tourism actor partnerships (A12), development of creative economy to support tourism businesses (A14), promotion of cultural products through cultural festivals (A15), development of tourism villages (A8), development of heritage tourism (A10), development of local resource-based tourism (A3), and development of spiritual tourism (A2).

4) For the infrastructure development and accessibility policy (P4), the actions that are closest and most relevant are the development of infrastructure networks as supporting facilities for tourism activities (A13), development of ICT (A7), development of accessibility/connectivity between tourist attractions (A5), and management of tourism destinations (A4).

5) For the community-based tourism management policy (P5), the closest and most relevant actions are enhancement of cross-sectoral, cross-government, and tourism actor partnerships (A12), development of agrotourism in rural areas (A9), development of creative economy to support tourism businesses (A14), promotion of cultural products through cultural festivals (A15), and capacity building and improvement of local community knowledge (A6). 


\section{Action/policy closeness map}

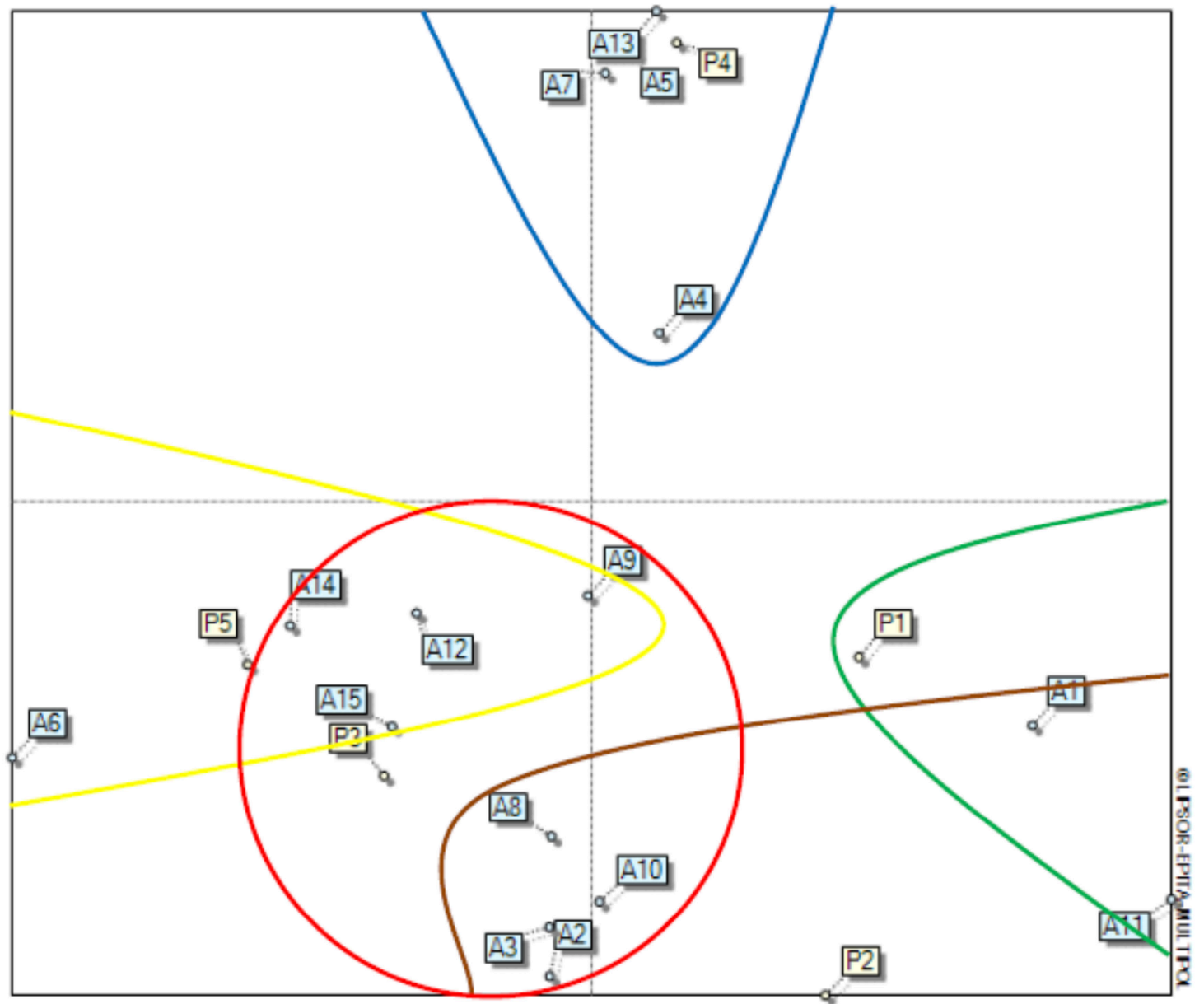

Figure 1. The linkage between policies and actions (MULTIPOL analysis results, 2020)

\subsubsection{Policy-to-Scenario-Based Evaluation}

Based on Table 4, it appears that the community-based tourism management policy (P5) is the best in the open development scenario (S1), while the conservation-based tourism policy (P2) scores higher than the other four policies in the integrated development scenario (S2). If seen from the average scores of the two scenarios, the policy that scores the highest is the regional potential-based tourism policy (P3), followed by the community-based tourism management policy (P5), and conservation-based tourism (P2), the three of which have the most significant influence among the five policies. Based on the scores of the established scenarios, the integrated development scenario (S2) is superior to the open development scenario (S1). 
Table 4. Scores of policies to scenarios

\begin{tabular}{|c|c|c|c|c|c|}
\cline { 2 - 6 } \multicolumn{1}{c|}{} & S1 & S2 & Moy. & Ec. Ty & Number \\
\hline P1 & 5.8 & 6.3 & 6.1 & 0.3 & 1 \\
\hline P2 & 5.4 & 8 & 6.7 & 1.3 & 3 \\
\hline P3 & 7.2 & 7.1 & 7.2 & 0.1 & 5 \\
\hline P4 & 6.2 & 6.2 & 6.2 & 0 & 2 \\
\hline P5 & 7.4 & 6.4 & 6.9 & 0.5 & 4 \\
\hline
\end{tabular}

Source: MULTIPOL analysis results, 2020

Like the linkage between policies and actions presented earlier in the closeness map, the MULTIPOL analysis also presents a closeness map to show the linkage between scenarios and policies as shown in Figure 2. As shown in Figure 2, regional potential-based tourism policy (P3), community-based tourism management (P5), and conservation-based tourism (P2) are strongly relevant in the integrated development scenario (S2) implementation, while for the open development scenario (S1) there are two most relevant policies, namely infrastructure development and accessibility (P4), and tourism planning regulation (P1).

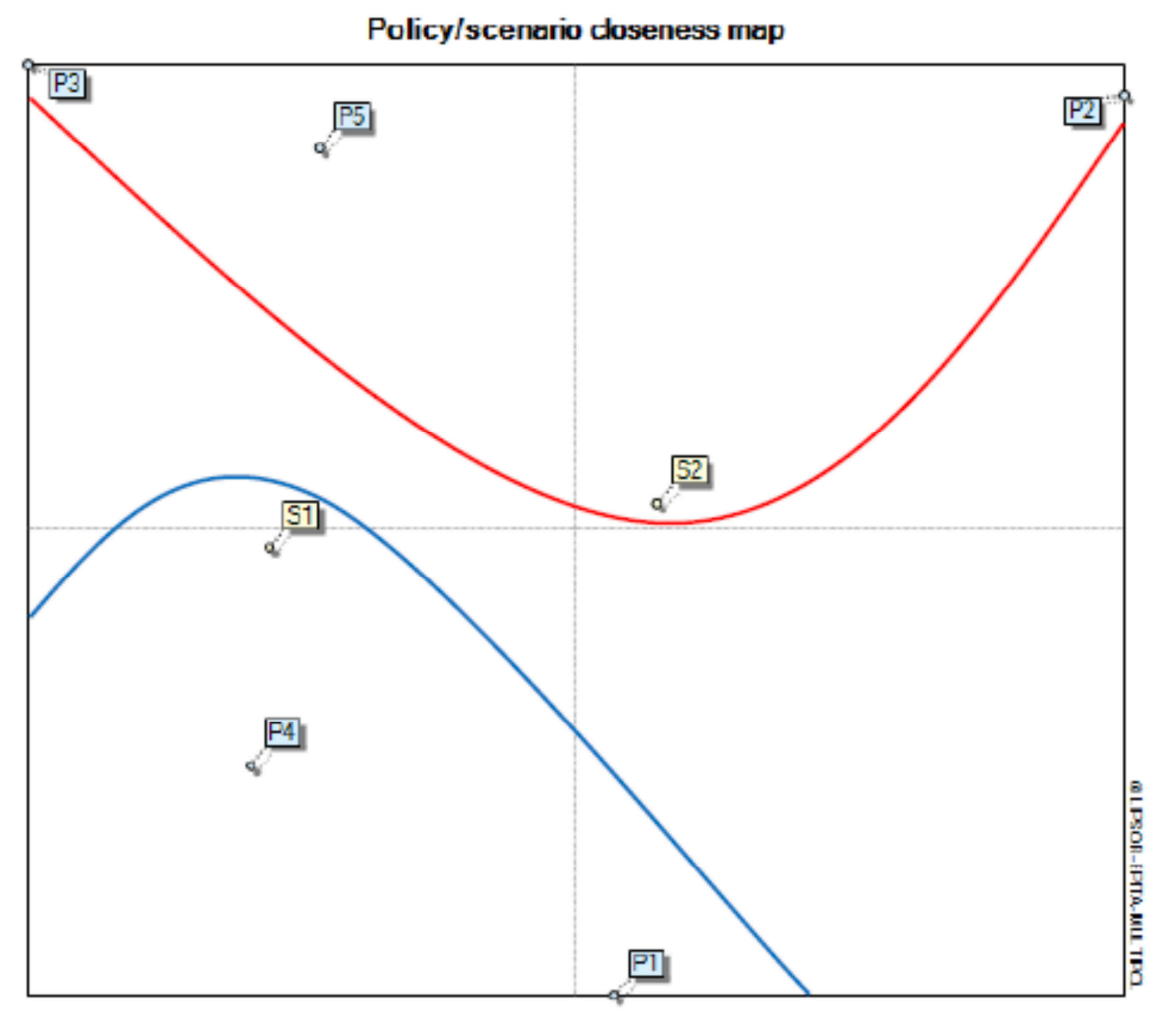

Figure 2. The closeness map showing the relationship between scenarios and policies (MULTIPOL analysis results, 2020) 


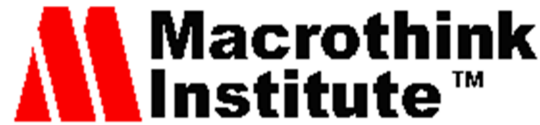

The overall results of the MULTIPOL analysis can be presented in the form of potential policy paths which can be implemented with actions that are in line with certain policies and scenarios (Panagiotopoulou and Stratigea, 2014). Figure 3 presents the potential policy paths that can be pursued through various actions that are in line with the policies. Both scenarios have different policies. Both for the open development scenario (S1) and integrated development scenario (S2), the same actions namely the development of a tourist attraction master plan (A1) and the establishment of conservation and cultivation zones in tourist areas (A11) are relevant in the implementation of tourism planning regulation policy (P1) and conservation-based tourism policy (P2).

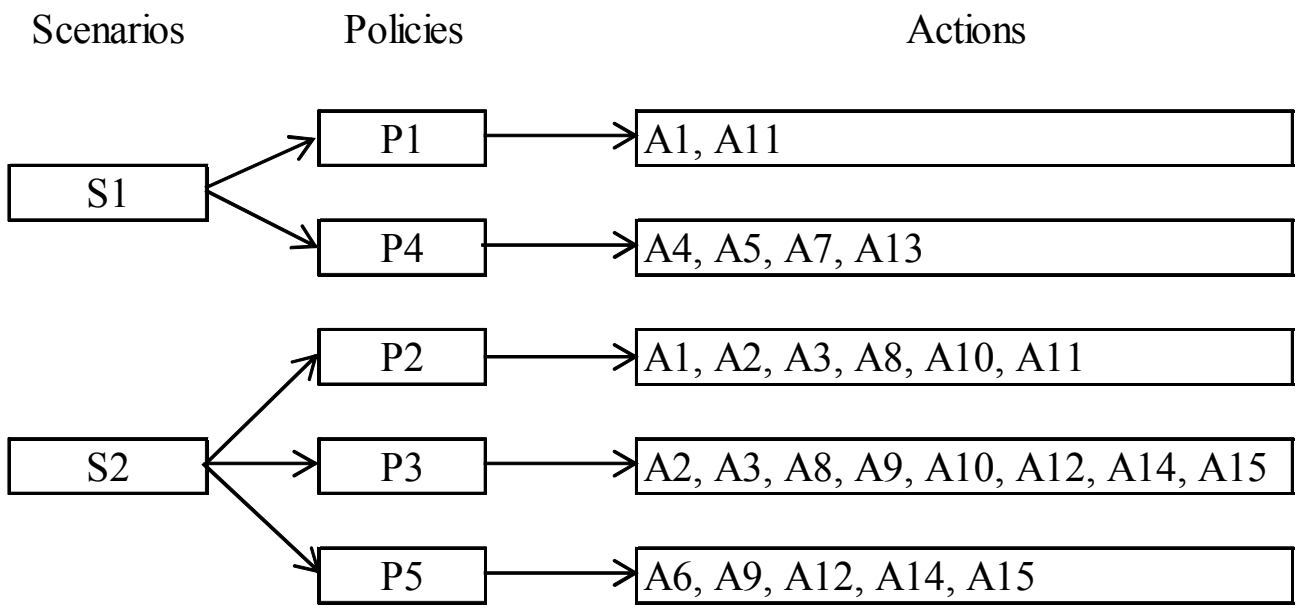

Figure 3. Potential path of policies and actions (MULTIPOL analysis results, 2020)

\section{Conclusion}

Based on the MULTIPOL (Multicriteria Policy) analysis, the development of tourism village action scored the highest for the conservation-based tourism policy, the regional potential-based tourism policy, infrastructure development and accessibility policy, and community-based tourism management policy. The policy with the highest score in relation to the established scenarios is the regional potential-based tourism policy. The other two policies which also scored high are the community-based tourism management policy and the conservation-based tourism policy. The three policies are strongly relevant in the implementation of the integrated development scenario.

\section{References}

Badan Pusat Statistik (BPS) Provinsi Bali. (2018). Provinsi Bali dalam Angka 2018.

Bello, F. G., Carr, N., \& Lovelock, B. (2016). Community participation framework for protected area-based tourism planning. Tourism Planning \& Development, 13(4), 469-485. http://dx.doi.org/10.1080/21568316.2015.1136838 
Chettiparamb, A., \& Thomas, H. (2012). Tourism and spatial planning. Journal of Policy Research in Tourism, Leisure and Events, 4(3), 215-220. https://doi.org/10.1080/19407963.2012.726157

Djuanedi, A. (2012). Proses Perencanaan Wilayah dan Kota. Yogyakarta: Gadjah Mada University Press.

Fauzi, A. (2019). Teknik Analisis Keberlanjutan. Jakarta: PT Gramedia Pustaka Utama.

Godet, M. (2001). Creating Future: Scenario Planning as Strategic Management Tool. Washington: Brooking Institution Press.

Godet, M., Monti, R., Meunier, F., \& Roubelat, F. (2004). Scenarios and Strategies: A Toolbox for Problem Solving. Paris: Cahiers du LIPSOR, Laboratory for investigation in Prospective and Strategy.

Kabupaten Karangasem. (2012). Peraturan Daerah Kabupaten Karangasem Nomor 17 Tahun 2012 tentang Rencana Tata Ruang Wilayah Kabupaten Karangasem Tahun 2012 2032.

Lew, A. A. (2017). Tourism planning and place making: place-making or placemaking?. Tourism Geographies, 19(3), 448-466. https://doi.org/10.1080/14616688.2017.1282007

Panagiotopoulou, M., \& Stratigea, A. (2014). A Participatory Methodological Framework for Paving Alternative Local Tourist Development Path: The Case of Sterea Ellada Region. European Journal of Futures Research, 2(44), 2-15. https://doi.org/10.1007/s40309-014-0044-7

Papageorgiou, M., \& Beriatos, E. (2011). Spatial Planning and Development in Tourist Destinations: A Survey in a Greek spa Town. International Journal of Sustainable Development and Planning, 6(1), 34-48. https://doi.org/10.2495/SDP-V6-N1-34-48

Provinsi Bali. (2009). Peraturan Daerah Provinsi Bali Nomor 16 Tahun 2009 tentang Rencana Tata Ruang Wilayah Provinsi Bali Tahun 2009 - 2029.

Putra, I. N. D., \& Paturusi, S. A. (editor). (2017). Metamorfosis Pariwisata Bali: Tantangan Membangun Pariwisata Berkelanjutan. Denpasar: Pustaka Larasan bekerjasama dengan Program Magister Kajian Pariwisata Fakultas Universitas Udayana.

Republik Indonesia. (2007). Undang-Undang Republik Indonesia Nomor 26 Tahun 2007 tentang Penataan Ruang.

Republik Indonesia. (2011). Peraturan Pemerintah Republik Indonesia Nomor 50 Tahun 2011 tentang Rencana Induk Pembangunan Kepariwisataan Nasional Tahun 2010 - 2025.

Risteski, M., Kocevski, J., \& Arnaudov, K. (2012). Spatial planning and sustainable tourism as basis for developing competitive tourist destinations. Procedia - Social and Behavioral Sciences, 44, 375-386. https://doi.org/10.1016/j.sbspro.2012.05.042

Ruhanen, L. (2004). Strategic planning for local tourism destinations: an analysis of tourism 


\section{Macrothink}

International Journal of Social Science Research

ISSN 2327-5510 2020, Vol. 8, No. 2

plans. Tourism and Hospitality Planning \& Development, 1(3), 239-253. http://dx.doi.org/10.1080/1479053042000314502

Stratigea, A. (2013). Participatory Policy Making in Foresight Studies at the Regional Level: A Methodelogical Approach. Regional Science Inquiry Journal, 5(1), 145-161. http://www.rsijournal.eu/ARTICLES/June_2013/9.pdf

\section{Copyright Disclaimer}

Copyright for this article is retained by the author(s), with first publication rights granted to the journal.

This is an open-access article distributed under the terms and conditions of the Creative Commons Attribution license (http://creativecommons.org/licenses/by/4.0/). 